\title{
The development of Pallaton raphanobrassica for New Zealand farming systems
}

\author{
Andrew DUMBLETON ${ }^{1 *}$, Gemma M. BOX ${ }^{1}$, Fiona FOLEY ${ }^{1}$, \\ Charlotte T. WESTWOOD ${ }^{1}$ and Emma M. WRIGHT ${ }^{1}$ \\ ${ }^{1}$ PGG Wrightson Seeds, 742 Tancreds Road, Lincoln 7676, New Zealand \\ *Corresponding author: adumbleton@pggwrightsonseeds.co.nz
}

\begin{abstract}
Raphanobrassica (Raphanus $x$ Brassica L., $c v$. 'Pallaton') is an allotetraploid, produced from kale (Brassica oleracea $\mathrm{L}$.) $\mathrm{x}$ radish (Raphanus raphanistrum subsp. sativus L.). It is a multi-graze forage, selected for high cumulative yield, water efficiency and resistance to clubroot (Plasmodiophora brassicae). This paper describes the breeding, agronomy and nutritive value of 'Pallaton', which can be grazed in situ between 42 and 70 days after sowing (DAS) with no specific crop maturity requirement. Cumulative yield of three consecutive harvests, analysed by meta-analysis of eighteen trials from 2013 to 2019 on three sites, showed 'Pallaton' had a greater yield of $16,254 \mathrm{~kg} \mathrm{DM} /$ ha than forage rape (B. napus spp. biennis, $c v$. 'Titan') and leafy turnip (B. rapa; syn. B. campestris $c v$. 'Pasja II') at 12,639 and $10,965 \mathrm{~kg} \mathrm{DM} / \mathrm{ha}$, respectively. A further trial, comparing nutritive values, demonstrated 'Pallaton' has a similar profile to 'Titan'. 'Pallaton' may be rotationally grazed for up to twelve months when initially grazed by livestock at $350-400 \mathrm{~mm}$ plant height between 42 and 70 DAS. Livestock consuming 'Pallaton' are susceptible to the same potential animal health concerns as other Brassica species, but represents a forage option for sheep, beef, deer and dairy farming, particularly those in challenging environments.
\end{abstract}

Keywords: Forage brassica, yield, nutritive value

\section{Introduction}

Forage brassica are fodder crops grown as part of rotation systems to produce additional summer, autumn or winter feed, where pasture growth is limited. Brassica crops, such as forage rape (Brassica napus ssp. biennis), leafy turnip (B. rapa; syn. B. campestris), bulb turnip (B. rapa ssp. rapifera or napobrassica; syn. B. campestris), swede (B. napus ssp. napobrassica or rapifera), and kale (B. oleracea ssp. Acephala), account for an estimated 300,000 ha (Dumbleton, et al., 2012) and 200,000 ha (D. Thomas, personal communication, 2020) of land use in New Zealand and Australia, respectively. These crops can provide high-quality feed options (de Ruiteret al., 2007; Westwood and Mulcock, 2012) and superior dry matter (DM) yields (Judson and Edwards, 2008) to traditional pasture swards, which are valuable during periods of low soil moisture (Fletcher et al., 2010) or limiting temperatures (Andreucci et al., 2012; 2016; Dumbleton, et al., 2012). Demand for flat cultivatable land for dairy production and horticulture has resulted in sheep, beef and deer enterprises being pushed to finish stock in more marginal land areas. This change requires forage crop options that are suitable for growing in land with lower soil moisture availability and low fertility. Raphanobrassica (cv. 'Pallaton') is a multigraze forage brassica species developed from a kale $\mathrm{x}$ radish hybrid. The breeding, agronomic performance and nutritive value of 'Pallaton' are described in this paper in comparison with other forage brassica options commonly grown on-farm.

\section{Breeding}

The need to expand forage brassica options for grazing animals in agronomically challenging conditions was a key driver for the formation of 'Forage Innovations Ltd.', a joint venture between Plant and Food Research and PGG Wrightson Seeds. The aim was to utilise intergeneric hybridisations between kale and radish. The expectation was that kale would provide high DM yields, quality and palatability traits, while the radish contributes increased drought, insect and disease tolerance traits. 'Pallaton' is an allotetraploid, which combines the genomes of more than one species. Naturally occurring allotetraploids most likely originate through either $2 \mathrm{n}$ gametes or chromosome doubling of chance F1 hybrids between two distinct species of the same genus, or from different genera (Baker et al., 2017). Early interspecific hybrids between Brassica and Raphanus species for human consumption were largely unsuccessful, until work by Russian geneticist Karpechenko (1928) successfully crossed B. oleracea ( $2 \mathrm{n}=18$, Figure 1$)$. and $R$. sativus $(2 \mathrm{n}=18)$. The hybrid formed from these two species is a diploid $(2 n=18)$, containing one set of kale chromosomes (CC genome, $\mathrm{n}=9$ ) and one set of radish chromosomes (RR genome, $\mathrm{n}=9$ ). However, these $\mathrm{F} 1$ progeny are sterile, forming gametes that contain one complete set of Brassica chromosomes and one complete set of Raphanus chromosomes.

Intergeneric hybrids are commonly crossincompatible, which results in the premature breakdown of endosperm and early abortion of embryos (Nishi et al., 1970). To restore fertility to the gamete, plants 


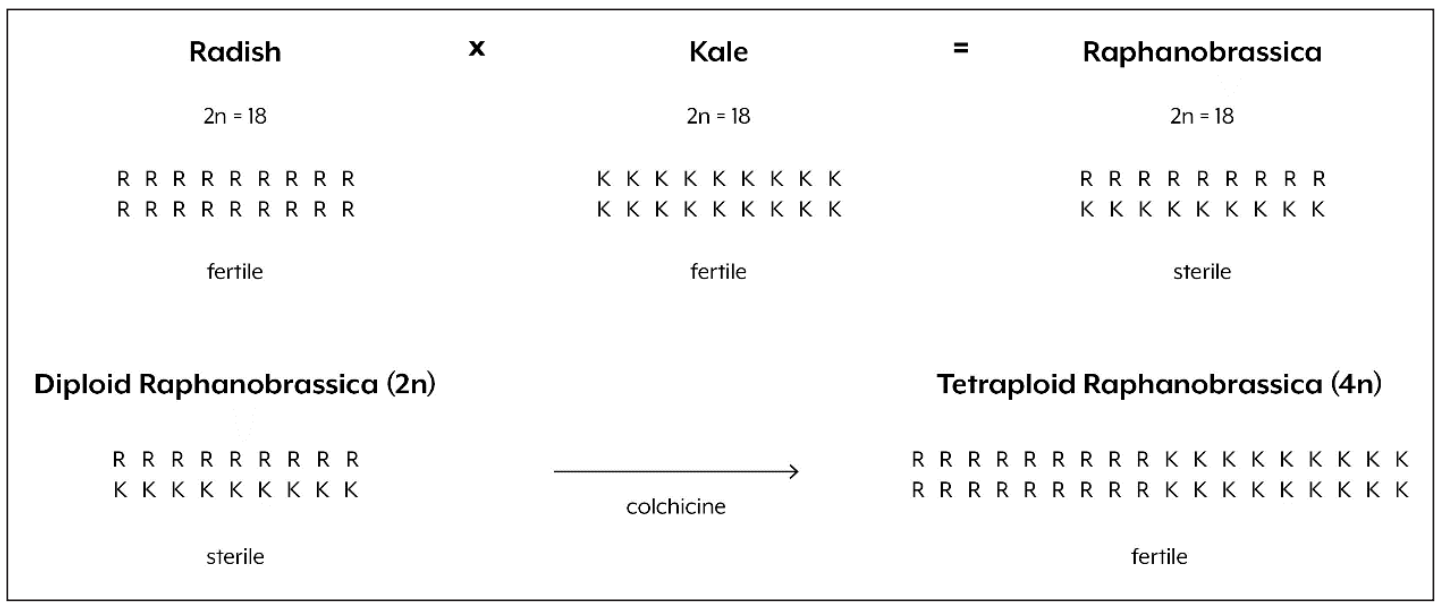

Figure 1 Development of interspecific fertile Raphanobrassica hybrids between Brassica and Raphanus by chromosomal doubling

are treated with colchicine, which induces polyploidy (Figure 1). This enables the pairing of chromosomes during meiosis. The colchicine treatment combined with different in vitro embryo rescue techniques (Rodrigues-Otubo et al., 2000) can produce a plant that contains two sets of $B$. oleracea chromosomes and two sets of $R$. sativus chromosomes $(4 \mathrm{n}=36)$, resulting in fertility in the F2 progeny.

'Pallaton' was selected from a phenotypically variable test population and viable and fertile, intergeneric single plant progeny then entered a traditional field plant breeding programme from 2003 2014. Over the twelve-year period, plants were selected for high cumulative forage yield; plant persistence under multiple grazing; reduction of the presence of early flowering; high water use efficiency (Chakwizira et al., 2021 in press); and glasshouse selection for clubroot resistance. The final candidate then underwent extensive regional trials that compared yield to existing forage rape and leafy turnip cultivars.

\section{Clubroot resistance}

Clubroot, caused by the Plasmodiophora brassicae fungus, is one of the most serious diseases of brassicas. Consequently, there has been a considerable effort in New Zealand and internationally to develop resistant cultivars. The genetics of resistance to clubroot is complex, due to there being multiple factors involved. These include the diverse sources of resistance among the plant genotypes, and the presence of the large and evolving population of clubroot pathotypes. Each individual raphanobrassica single plant progeny was screened for clubroot resistance using a glasshouse screening assay against the most pathogenic Southland field isolate (SLD1), which has heavily infected the clubroot-resistant swede variety 'Aparima Gold'.
Individual plants were inoculated with a known amount of SLD1, grown for four to six weeks (dependent on growth rate) and scored from 0 (no disease symptoms) to 3 (heavily infected). Matilda (B. rapa) was used as the susceptible control and achieved an infection score of 3, compared to the parent plants of 'Pallaton' which had an average infection score of 1 .

\section{Agronomic performance}

Eighteen plot trials were carried out between 2013 and 2019 to assess the yield and regrowth potential of 'Pallaton' raphanobrassica with control cultivars across several brassica species (Table 1). 'Pallaton' was entered in all eighteen trials, early maturing forage rape ( $c v$. 'Titan') in sixteen of the eighteen and leafy turnip ( $c v$. 'Pasja II') in four of the eighteen. Trials were located across three sites, with sixteen occurring at an irrigated site at Kimihia Research Centre in Lincoln, Canterbury, one on a non-irrigated farm near Oxford, North Canterbury, and one at a non-irrigated site at Ruakura Research Centre in Hamilton, Waikato.

All trials had a complete randomised block design, with sixteen trials having four replicates, one with three replicates (trial 4), and one with six replicates (trial 18). All were spring sown in mid to late October. Plot sizes differed at sites: $1.2 \times 6 \mathrm{~m}$ at Kimihia Research Centre and $1.5 \times 6 \mathrm{~m}$ at both Oxford and Ruakura Research Centre. All plots were drilled in $150 \mathrm{~mm}$ drill rows at a depth of $<10 \mathrm{~mm}$ using an Oyjord cone seeder with a sowing rate of $4 \mathrm{~kg} / \mathrm{ha}$ for 'Titan' and 'Pasja II' and 8 $\mathrm{kg} / \mathrm{ha}$ of 'Pallaton'.

All trials (except six, seventeen and eighteen) were harvested $100 \mathrm{~mm}$ above soil level, with Wintersteiger Cibus $\mathrm{F}$ forage plot harvester. Total plot fresh weight $(\mathrm{kg})$ was measured by the plot harvester. Subsamples of approximately 400 grams per plot were collected 
and weighed before and after herbage was dried in a purpose-built oven at $90^{\circ} \mathrm{C}$ for 48 hours, then used to calculate DM percentage.

Trial eighteen was assessed by cutting a $1 \mathrm{~m}^{2}$ quadrat per plot to $100 \mathrm{~mm}$ above soil level, with the remainder grazed with sheep to a residual of $100 \mathrm{~mm}$. Trials six and seventeen, were measured as for trial eighteen, but remaining biomass was removed by mowing with a ride on mower to the $100 \mathrm{~mm}$ residual.

There were three harvesting events in each trial, defined by optimum crop maturity of control cultivars for harvest one. Regrowth cuts, harvest two and three were determined by either or both variables: growth and time. Harvest one occurred from 53 - 112 DAS, harvest two events from $30-84$ days after harvest one and harvest three events from $33-87$ days after the second harvest.

The data from all trials were analysed using a combined restricted maximum likelihood (REML) meta-analysis, with cultivar and cultivar $\mathrm{x}$ cut length (days between harvests) as fixed effects, fitting trials and replicates as blocking terms and allowing each trial to have its own residue variance. This was fitted with Genstat 21 (VSN International, 2020) using $\alpha=0.05$.

Yield from Harvest 1, 2 and 3, total cumulative yield, yield by day effect 1, 2, 3 and total yield by day effect were analysed with mean days reported for each growth period (Table 2). Yield by day effect quantified the differences between cultivars, relative to 'Pallaton' thus always having a value of zero when days to harvest differ from mean days.

The first trial was conducted in 2013, whereby the yield of 'Pallaton' was compared with conventional forage brassica cultivars with a range of different maturity types. These included, early and late maturing forage rape (recommended grazing $70-120$ DAS), through to longer maturing kale cultivars $(150-200$ DAS). Throughout these first trials, 'Pallaton' had relatively high yields early in crop life, comparable with forage rape and kale. A reduction in leaf senescence, typically seen with other forage brassica species also allowed increased grazing flexibility of 'Pallaton' up to 100 DAS. However, crop utilisation, regrowth potential and feed quality were reduced with delaying grazing (150 - 200 DAS). Subsequently, trial four and trial sixteen respectively compared 'Pallaton' to a range of early maturing leafy turnip and forage rape cultivars, with trials often including harvesting several regrowth events. Through this process, the place of 'Pallaton' in farming enterprises was defined. Current recommendations are that the first graze of 'Pallaton' should occur at $42-$ 70 DAS when plant height is between $350-400 \mathrm{~mm}$ and continued repeat grazings can occur as plant height regrows to the maximum of $400 \mathrm{~mm}$.

Table 1 Overview of eighteen trials in combined trial analysis of raphanobrassica (cv. 'Pallaton'), forage rape (cv. 'Titan') and leafy turnip (cv. 'Pasja II').

\begin{tabular}{|c|c|c|c|c|c|c|c|}
\hline Trial No. & Year & Location & Replicates & $\begin{array}{l}\text { Sowing date } \\
\text { (dd/mm/yy) }\end{array}$ & $\begin{array}{c}\text { Harvest* }^{*} \\
\text { (days) }\end{array}$ & $\begin{array}{l}\text { Harvest } 2 \\
\text { (days) }\end{array}$ & $\begin{array}{c}\text { Harvest } 3 \\
\text { (days) }\end{array}$ \\
\hline 1 & 2013 & Kimihia & 4 & $24 / 10 / 13$ & 82 & 66 & 60 \\
\hline 2 & 2014 & Kimihia & 4 & $23 / 10 / 14$ & 89 & 64 & 57 \\
\hline 3 & 2015 & Kimihia & 4 & $30 / 10 / 15$ & 53 & 30 & 33 \\
\hline 4 & 2015 & Kimihia & 3 & $30 / 10 / 15$ & 98 & 70 & 87 \\
\hline 5 & 2016 & Kimihia & 4 & $13 / 10 / 16$ & 110 & 70 & 83 \\
\hline 6 & 2016 & Oxford & 4 & $18 / 10 / 16$ & 87 & 75 & 61 \\
\hline 7 & 2016 & Kimihia & 4 & $13 / 10 / 16$ & 98 & 82 & 83 \\
\hline 8 & 2016 & Kimihia & 4 & $13 / 10 / 16$ & 112 & 69 & 82 \\
\hline 9 & 2017 & Kimihia & 4 & $24 / 10 / 17$ & 55 & 35 & 37 \\
\hline 10 & 2017 & Kimihia & 4 & $25 / 10 / 17$ & 84 & 63 & 58 \\
\hline 11 & 2017 & Kimihia & 4 & $24 / 10 / 17$ & 91 & 63 & 52 \\
\hline 12 & 2018 & Kimihia & 4 & $19 / 10 / 18$ & 56 & 39 & 37 \\
\hline 13 & 2018 & Kimihia & 4 & $19 / 10 / 18$ & 82 & 57 & 60 \\
\hline 14 & 2018 & Kimihia & 4 & $19 / 10 / 18$ & 96 & 54 & 66 \\
\hline 15 & 2019 & Kimihia & 4 & $21 / 10 / 19$ & 94 & 40 & 65 \\
\hline 16 & 2019 & Kimihia & 4 & 09/10/19 & 65 & 40 & 44 \\
\hline 17 & 2019 & Ruakura & 4 & $17 / 10 / 19$ & 62 & 84 & 71 \\
\hline 18 & 2019 & Kimihia & 6 & 29/10/19 & 69 & 50 & 59 \\
\hline
\end{tabular}

* Harvest 1 = days to first harvest; Harvest 2 and Harvest 3 = days from previous harvest. 
'Pallaton' and 'Titan' were not different $(\mathrm{P}>0.05)$ at Harvest 1, and produced 9,010 and 9,073 kg DM/ha, respectively (Table 2). However, both yielded more $(\mathrm{P}<0.001)$ than 'Pasja II' at $6,745 \mathrm{~kg} \mathrm{DM} / \mathrm{ha}$. At the second harvest (Harvest 2) 'Pallaton' yielded 4,839 kg $\mathrm{DM} /$ ha, significantly more than 'Titan' and 'Pasja II' at $2,735 \mathrm{~kg} \mathrm{DM} / \mathrm{ha}$ and $3,154 \mathrm{~kg} \mathrm{DM} /$ ha respectively $(\mathrm{P}<0.001)$. At the third harvest (Harvest 3), 'Pallaton' yielded 2,007 $\mathrm{kg} \mathrm{DM} / \mathrm{ha}$, which was again more $(\mathrm{P}<0.001)$ than 'Titan', $1137 \mathrm{~kg} \mathrm{DM} / \mathrm{ha}$, and 'Pasja II', $1,063 \mathrm{~kg} \mathrm{DM} / \mathrm{ha}$.

Total cumulative yield across harvests, showed 'Pallaton' produced 16,254 kg DM/ha, which was more $(\mathrm{P}<0.01)$ than 'Titan' $(12,639 \mathrm{~kg} \mathrm{DM} / \mathrm{ha})$, and 'Pasja II' $(10,965 \mathrm{~kg} \mathrm{DM} / \mathrm{ha})$. The initial yield of 'Titan' in these trials was comparable to the expected crop yields of early maturing forage rapes $(70-90$ DAS) at $8-10.5$ t DM/ha (de Ruiter et al., 2009). Although, there was difficulty comparing studies, due to crop yields being highly influenced by environmental conditions, crop management and husbandry (Keogh et al., 2011).

Yield by day effect compared expected yield differences between 'Pallaton', 'Titan' and 'Pasja II' according to the period of growth when days to harvest differ from reported mean days. For example, at Harvest 2 (Table 2), if harvesting was at 60 days after the previous harvest, 'Titan' produced 2,104 kg DM/ ha $(\mathrm{P}<0.05)$ less than 'Pallaton'. The yield difference outside mean harvesting days can be calculated using the following equation, where DAS can be used interchangeably with days after the previous harvest.

\section{Yield difference $_{x D A S}=$ Yield difference ${ }_{\text {means DAS }}{ }^{+}$Yield by day effect $x$ DAS difference}

For example, if 'Pallaton' and 'Titan' crops were then harvested at 'Harvest 2', 75 days after previous harvest instead of 60 days, the expected difference in yield between these two species was $2884 \mathrm{~kg} \mathrm{DM} / \mathrm{ha}$ in favour of 'Pallaton', i.e.:

Yield difference $_{75 D A S}=-2104+(-52) \times(75-60)$ Yield difference F $_{75 A S}=-2884 \mathrm{~kg} \mathrm{DM} / \mathrm{ha}$

Another example, if 'Pallaton' and 'Pasja II' crops were then harvested at 'Harvest 3', 50 days after the previous harvest instead of 63 days, the expected difference in yield between these two species is 1139 $\mathrm{kg} \mathrm{DM} / \mathrm{ha}$ in favour of 'Pallaton', i.e.:

Yield difference $_{50 \text { DAS }}=-944+(15) \times(50-63)$

Yield difference SODAS $=-1139 \mathrm{~kg} \mathrm{DM} / \mathrm{ha}$

\section{Nutritive value}

A randomised complete block trial with four replicates was established at an irrigated site at Kimihia Research Centre, Lincoln, Canterbury to compare the nutritive value of 'Pallaton' and 'Titan'. Four 0.5 ha replicates of each brassica were sown on 1 November 2017 following an application of $250 \mathrm{~kg} / \mathrm{ha}$ of diammonium phosphate. At 69 DAS, three randomly selected $1 \mathrm{~m}^{2}$ quadrat samples per plot were cut to $3 \mathrm{~cm}$ above soil level and manually separated into leaf and petiole, and stem. Approximately $300 \mathrm{~g}$ of plant material from each plot of each brassica species was chilled and transported to a commercial laboratory (R J Hill Laboratories Ltd, Hamilton, New Zealand) for wet chemistry analysis of DM, metabolisable energy (MJME), digestibility (DOMD), crude protein (CP), acid detergent fibre (ADF), neutral detergent fibre (NDF), soluble sugars (SS), lignin and ash (Table 3). Two whole plants per plot from two replicates of each brassica species were freeze-dried and transported to Plant and Food Research, Lincoln, Canterbury for analysis of glucosinolate concentrations. Data were analysed using analysis of variance (ANOVA) implemented in GENSTAT Version

Table 2 Yield (kg DM/ha) at three harvesting events (Harvest 1-3) for raphanobrassica (cv. 'Pallaton'), forage rape (cv. 'Titan') and leafy turnip (cv. 'Pasja II') combined over eighteen trials $(2013-2019)$ at three sites in New Zealand.

\begin{tabular}{|c|c|c|c|c|c|c|c|c|}
\hline Cultivar & $\begin{array}{l}\text { Harvest } 1 \\
\text { kg DM/ha }\end{array}$ & $\begin{array}{l}\text { Yield by day } \\
\text { effect } 1\end{array}$ & $\begin{array}{l}\text { Harvest } 2 \\
\mathrm{~kg} \mathrm{DM} / \mathrm{ha}\end{array}$ & $\begin{array}{c}\text { Yield by day } \\
\text { effect } 2\end{array}$ & $\begin{array}{l}\text { Harvest } 3 \\
\mathrm{~kg} \mathrm{DM} / \mathrm{ha}\end{array}$ & $\begin{array}{l}\text { Yield by day } \\
\text { effect } 3\end{array}$ & $\begin{array}{l}\text { Total yield } \\
\text { kg DM/ha }\end{array}$ & $\begin{array}{c}\text { Total yield } \\
\text { by day effect }\end{array}$ \\
\hline 'Pallaton' & $9010^{a}$ & 0 & $4839^{a}$ & 0 & $2007^{a}$ & 0 & $16254^{a}$ & 0 \\
\hline ‘Titan’ & $9073^{a}$ & -18 & $2735^{b}$ & -52 & $1137^{b}$ & -3 & $12639^{b}$ & -18 \\
\hline 'Pasja II' & $6745^{b}$ & -50 & $3154^{b}$ & -54 & $1063^{b}$ & 15 & $10965^{b}$ & -36 \\
\hline Mean days & & 86 & & 60 & & 63 & & 209 \\
\hline $\mathrm{P}$-value & $<0.001$ & $<0.001$ & $<0.001$ & $<0.001$ & $<0.001$ & $<0.001$ & $<0.001$ & $<0.001$ \\
\hline Wald/df & 366.58 & 97.33 & 1156.93 & 208.22 & 1821.48 & 107.65 & 785.41 & 113.05 \\
\hline $\mathrm{LSD}_{5 \%}$ & 867 & & 615 & & 251 & & 1412 & \\
\hline
\end{tabular}

* Yield by day effect was the difference between two entries by each extra day of growth relative to 'Pallaton'. Subscript letters in common represent means that are not significantly different $(\mathrm{P}>0.05)$ using Duncan's new multiple range test. 
19 with significance declared at $\mathrm{P}<0.05$.

'Pallaton' and 'Titan' plants were harvested at 69 DAS, a relatively long sowing to grazing interval for 'Pallaton' so nutritive value data may not fully representative of plant nutritive value for 'Pallaton'. A more suitable test would be to compare 'Pallaton' against an earlier maturing forage brassica, leafy turnip (grazed $42-70$ DAS).

'Titan' had a higher DM $(\mathrm{P}<0.001)$ than 'Pallaton' at $9.6 \% \mathrm{DM}$ and $8.1 \% \mathrm{DM}$, respectively (Table 3), both DM values were relatively low, compared to previous studies. Higher values for forage rapes have been recorded, for example 13.8\% (Keim et al., 2020), 14.3\% (Westwood and Mulcock, 2012) and 14.5\% (Islam et al., 2012), reflecting the impacts of variable environmental conditions, crop management practices (Keogh et al., 2011) and cultivar selection (Westwood and Mulcock, 2012).

Leaf proportion was high $(\mathrm{P}<0.05)$ for 'Pallaton' compared with 'Titan' at $91.5 \%$ and $83.3 \%$, respectively. Conversely whole plant ME was lower $(\mathrm{P}=0.033)$ for 'Pallaton' (12.2 MJME/kgDM) than 'Titan' (12.4 MJME $/ \mathrm{kgDM}$ ). The MJME content was high for both brassica species, compared to typical MJME content of summer pastures, particularly under dry conditions.

Soluble sugar content of 'Titan' and 'Pallaton' differed significantly $(\mathrm{P}<0.001)$ at $18.2 \%$ and $16.0 \%$, respectively. Levels of SS in 'Titan' and 'Pallaton' were higher than those reported for forage rape of $9.8 \%$ non-structural carbohydrate (Keim et al., 2020) but relatively low compared to values for rape of between $25.1 \%$ and $29.8 \%$ water soluble carbohydrate for seven cultivars of forage rape (Westwood and Mulcock, 2012). Soluble sugar content of forage brassicas can be highly variable, for example water soluble carbohydrate content of 'Goliath' rape ranged from 9.0\% - 18.4\% (Islam et al., 2012), with variation attributed to sowing date, DAS and first versus subsequent harvests of forage regrowth. The higher SS content of 'Titan' may reflect the early maturity of 'Titan' (70 - 90 DAS) compared to 'Pallaton', which does not mature. Future studies could consider sequential harvests of 'Titan' and 'Pallaton' to investigate time by SS and other plant quality attribute, interactions as plants approach or pass maturity.

Ash content was significantly $(\mathrm{P}<0.001)$ higher for 'Pallaton' than 'Titan' (Table 3). Ash content provides an approximation of mineral content of feed as well as an indicator of possible soil contamination. Other investigations of mineral content of 'Pallaton' (Foley, pers.comm.) revealed a similar profile of minerals to other Brassica species; so, the variance in ash content remained unexplained.

Crude protein content of 'Titan' and 'Pallaton' was high for both species at 21.3 and $22.1 \% \mathrm{CP}$, respectively, and did not differ significantly $(\mathrm{P}=0.28)$ between species. Sowing date, grazing and management practices including $\mathrm{N}$ fertiliser application (Islam et al., 2012; Keogh et al., 2011) brassica species and cultivar (Westwood and Mulcock 2012) can all influence the CP content of forage Brassica species. Neutral detergent fibre and ADF content did not differ significantly $(\mathrm{P}>0.05)$ between 'Titan' and 'Pallaton'; values were similar to those previously reported for forage rape (Islam et al., 2012; Keim et al., 2020; Westwood and Mulcock, 2012).

'Pallaton' contained low concentrations of the glucosinolates epiprogoitrin $(\mathrm{P}<0.001)$ and progoitrin $(\mathrm{P}<0.001)$, with concentrations of 0.14 and 3.32 $\mu \mathrm{mol} / \mathrm{g}$ DM, respectively. In contrast, 'Titan' contained $0.30 \mu \mathrm{mol} / \mathrm{g}$ DM epiprogoitrin and $8.40 \mu \mathrm{mol} / \mathrm{g}$ DM progoitrin. Nitrile and epithionitrile derivatives of progoitrin have been implicated as potential hepatotoxins in a cattle-specific condition known as 'Brassica Associated Liver Disease' (BALD) (Collett et al., 2020). The concentration at which progoitrin may induce BALD in cattle is unknown and the risk

Table 3 Proportion of leaf and stem and whole plant nutritive value ( $n=48)$ for raphanobrassica ( $c v$. 'Pallaton') and forage rape (cv. 'Titan') as percentage dry matter (DM).

\begin{tabular}{lccccccccccc}
\hline Cultivar & Leaf \% & Stem \% & DM \% & MJ ME & DOMD & CP & ADF & NDF & SS & Lignin & Ash \\
\hline 'Pallaton' & 91.5 & 8.7 & 8.1 & 12.2 & 76.1 & 22.1 & 19.3 & 22.2 & 16.0 & 4.6 & 15.7 \\
'Titan' & 83.3 & 16.6 & 9.6 & 12.4 & 77.4 & 21.3 & 18.2 & 21.9 & 18.2 & 4.8 & 13.6 \\
P-value & $<0.001$ & $<0.001$ & $<0.001$ & 0.039 & 0.033 & 0.280 & 0.078 & 0.800 & $<0.001$ & 0.582 & $<0.001$ \\
S.E.M. & $<0.01$ & $<0.01$ & 0.14 & 0.07 & 0.42 & 0.56 & 0.41 & 0.70 & 0.43 & 0.14 & 0.28 \\
LSD $_{5 \%}$ & 0.02 & 0.03 & 0.40 & 0.19 & 1.18 & 1.58 & 1.15 & 1.97 & 1.21 & 0.39 & 0.80 \\
\hline
\end{tabular}

$\mathrm{DM} \%=$ dry matter percentage;

$\mathrm{MJME}=$ megajoules of metabolisable energy;

DOMD = digestibility;

$\mathrm{CP}=$ crude protein;

$\mathrm{ADF}=$ acid detergent fibre

$\mathrm{NDF}=$ neutral detergent fibre $; \mathrm{SS}=$ soluble sugars 
is influenced by multiple plant and animal factors, including brassica species, onset of the development of plant reproductive structures, use of $\mathrm{N}$ and $\mathrm{S}$ fertiliser, animal age, concurrent presence of rumen acidosis, and animal physiological state, specifically late gestation in cattle (Dalley et al., 2015). Progoitrin concentrations of $30 \mu \mathrm{mol} / \mathrm{g}$ DM or more in swedes may induce BALD under some but not all conditions. An investigation of an outbreak of BALD in dairy cattle consuming swedes during 2014 (Dalley et al., 2015) revealed a mean progoitrin concentration for all parts of swede plants of $24.8 \mu \mathrm{mol} / \mathrm{g} \mathrm{DM}$, with reproductive parts of swede plants containing more than $35 \mu \mathrm{mol} / \mathrm{g} \mathrm{DM}$.

With a whole plant progoitrin content of less than the $10 \%$ reported for reproductive sections of swedes, the risk of BALD in cattle consuming 'Pallaton' should be considered relatively low. However, animal health could still be compromised if high-risk factors are present, such as inappropriately high use of $\mathrm{N}$ and $\mathrm{S}$ fertilisers; a high proportion of flowering plant parts; and/or concurrent presence of rumen acidosis in cattle, particularly during the latter stages of gestation.

\section{Conclusions}

Raphanobrassica ( $c v$. 'Pallaton'), a hybrid of kale $\mathrm{x}$ radish, represents a new forage brassica option for New Zealand and Australian farming systems. 'Pallaton' was evaluated for yield and regrowth in eighteen trials over six years against two other brassica species. It had a greater cumulative yield, particularly in regrowth harvest events, than the forage rape 'Titan' or leafy turnip 'Pasja II', which suggested superior regrowth. Based on single-site data, the feed profile of 'Pallaton' was largely comparable with 'Titan' and similar to other published values, hence it represents a viable feed option for sheep, beef, deer and dairy enterprises.

\section{ACKNOWLEDGEMENTS}

This research was supported by Forage Innovation Ltd., a collaboration between PGG Wrightson Seeds and Plant and Food Research and by funding from the Primary Growth Partnership fund. The authors would like to thank Dr David Baird, who provided insight and expertise that greatly assisted this research and statistical analysis, and Dr Simon Bulman and Dr Farhat Shah for clubroot glasshouse screening.

\section{REFERENCES}

Andreucci, M. P., Black, A., \& Moot, D. J. (2012). Cardinal temperatures and thermal time requirements for germination of forage brassicas. Agronomy New Zealand, 42, 181-191.

Andreucci, M. P., Moot, D. J., Black, A. D., \& Sedcole, R. (2016). A comparison of cardinal temperatures estimated by linear and nonlinear models for germination and bulb growth of forage brassicas. $E u$ ropean Journal of Agronomy, 81, 52-63. https://doi. org/10.1016/j.eja.2016.08.010

Baker, R. L., Yarkhunova, Y., Vidal, K., Ewers, B. E., \& Weinig, C. (2017). Polyploidy and the relationship between leaf structure and function: implications for correlated evolution of anatomy, morphology, and physiology in Brassica. BMC Plant Biologu, 17(3). https://doi.org/10.1186/s12870-016-0957-3

Chakwizira, E., Dumbleton, A., Maley, S. (2021). Water use efficiency of raphanobrassica and forage rape. Agronomy Society of New Zealand, in press.

Collett, M. G., Matthews, Z. M., \& Parton, K. H. (2020). Hepatotoxicity of two progoitrin-derived nitriles in New Zealand white rabbits. Toxins, 12(11), 695-708. https://doi.org/10.3390/toxins12110695

Dalley, D., Verkerk, G., Kyte, R., McBeth, C., Petch, S., Kuhn-Sherlock, B., . . Morley, C. (2015). Swede associated toxicity in dairy cattle during winter 2014. Hamilton, New Zealand: DairyNZ.

de Ruiter, J. M., Dalley, D. M., Hughes, T. P., Fraser, T. J., \& Dewhurst, R. J. (2007). Types of supplements: Their nutritive value and use. In P. V. Rattray, I. M. Brookes, \& A. M. Nicol, Pasture and supplements for grazing animals (pp. 97-115). New Zealand Society of Animal Production Occasional Publication No. 14. https://agris.fao.org/agris-search/search. do?recordID=US201300122197

de Ruiter, J., Wilson, D., Maley, S., Fletcher, A., Fraser, T., Scott, W., . . Nichol, W. (2009). Management practices for forage brassicas. Christchurch, New Zealand: Forage Brassica Development Group.

Dumbleton, A., Gowers, S., Conner, A., Christie, M., Kenny, P., Mulcock, H., \& Charteris, B. (2012). Cleancrop(TM) Brassica System: The development of herbicide . Proceedings of the New Zealand Grassland Association, 74, 25-30.

Fletcher, A. L., Sinton, S. M., Gillespie, R. N., Maley, S., Sim, R. E., de Ruiter, J. M., \& Meenken, E. D. (2010). Drought response and water use efficiency of forage brassica. Agronomy New Zealand, 105-117. https:// www.cabdirect.org/cabdirect/abstract/20143056229

Griffiths, A. J., Gelbart, W. M., \& Miller, J. H. (1999). Modern genetic analysis: Changes in chromosome number. New York: Freeman. https://www.ncbi.nlm. nih.gov/books/NBK21229/

Harberd, D. J., \& McArthur, E. D. (1980). Meiotic analysis of some species and genus hybrids in the Brassiceae. In S. Tsunoda, K. Hinata, \& C. (. GomezCampo, Brassica Crops and Wild Allies, Biology and Breeding (pp. 65-87). Tokyo: The Japan Science Society Press. https://www.cabdirect.org/cabdirect/ abstract/19801689305

Islam, M. R., Garcia, S. C., \& Horadagoda, A. (2012). Effects of residual nitrogen, nitrogen 
fertilizer, sowing date and harvest time on yield and nutritive value of forage rape. Animal Feed Science and Technology, 177(1-2), 52-64. https://doi. org/10.1016/j.anifeedsci.2012.08.002

Judson, H. G., \& Edwards, G. R. (2008). Survey of management practice of dairy cows grazing kale in Canterbury. Proceedings of the New Zealand Grassland Association, 70, 249-254.

Karpechenko, G. D. (1928). Polyploid hybrids of Raphanus sativus X Brassica oleracea L. Bulletin of Applied Botany, 17, 305-408. https://doi.org/10.1007/ BF01740955

Keim, J. P., Gandarillas, M., Benavides, D., Cabanilla, J., Pulido, R. G., Balocchi, O. A., \& Bertrand, A. (2020). Nutrient concentrations and profile of non-structuralcarbohydrates vary among different Brassica forages. Animal Production Science, 60(12), 1503-1513. https://doi.org/10.1071/AN19472

Keogh, B., McGrath, T., \& Grant, J. (2011). The effect of sowing date and nitrogen on the dry-matter yield and nitrogen content of forage rape (Brassica napus L.) and stubble turnips (Brassica rapa L.) in Ireland.
Grass and Forage Science, 67(1), 2-12. https://doi. org/10.1515/2161-962X.1011

Nishi, S., Kawada, J., \& Toda, M. (1970). Studies on the embryos culture in vegetable crops. III. On the conditions affecting to embryo culture of interspecific hybrids between cabbage and Chinese cabbage. (pp. 73-88). Japan, Ser. A9: Bulletin of Horticultural Research. https://www.cabdirect.org/ cabdirect/abstract/19710306414

Rodrigues-Otubo, B. M., de Penteado, M. I., \& do Valle, C. B. (2000). Embryo rescue of interspecific hybrids of Brachiaria spp. Plant Cell, Tissue and Organ Culture, 61, 175-182. https://doi. org/10.1023/A:1006478407814

VSN International. (2020). GENSTAT for Windows 21st Edition. Retrieved from VSN International, Hemel, Hempstead, United Kingdom: genstat.co.uk

Westwood, C. T., \& Mulcock, H. (2012). Nutritive evaluation of five species of forage brassica. Proceedings of the New Zealand Grassland Association, 74, 31-38. 